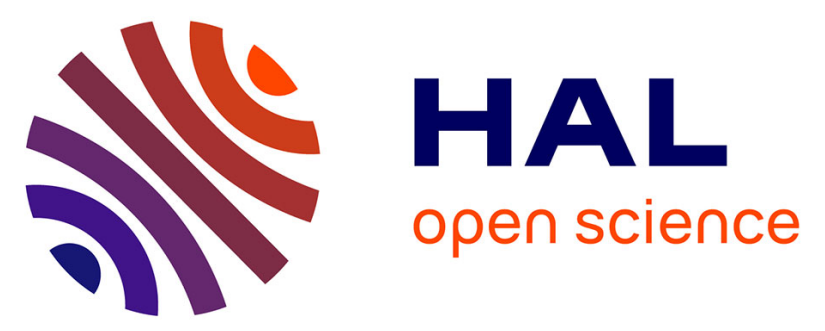

\title{
Differences in oviposition behaviour of two sympatric sibling species of the Ostrinia genus
}

Thibaut Malausa, Benjamin Pélissié, Véronique Piveteau, Denis D. Bourguet, Sergine Ponsard

\section{- To cite this version:}

Thibaut Malausa, Benjamin Pélissié, Véronique Piveteau, Denis D. Bourguet, Sergine Ponsard. Differences in oviposition behaviour of two sympatric sibling species of the Ostrinia genus. Bulletin of Entomological Research, 2008, 98 (2), pp.193-201. 10.1017/S0007485307005536 . hal-02657452

\section{HAL Id: hal-02657452 \\ https://hal.inrae.fr/hal-02657452}

Submitted on 12 Aug 2020

HAL is a multi-disciplinary open access archive for the deposit and dissemination of scientific research documents, whether they are published or not. The documents may come from teaching and research institutions in France or abroad, or from public or private research centers.
L'archive ouverte pluridisciplinaire HAL, est destinée au dépôt et à la diffusion de documents scientifiques de niveau recherche, publiés ou non, émanant des établissements d'enseignement et de recherche français ou étrangers, des laboratoires publics ou privés.

\section{다)(1) $(5$}

Distributed under a Creative Commons Attribution - NonCommercial| 4.0 International 


\title{
Differences in oviposition behaviour of two sympatric sibling species of the genus Ostrinia
}

\author{
T. Malausa ${ }^{1,2 *}$, B. Pélissié ${ }^{1}$, V. Piveteau ${ }^{1}$, C. Pélissier ${ }^{1}$, \\ D. Bourguet ${ }^{2}$ and S. Ponsard ${ }^{\mathbf{1}}$ \\ ${ }^{1}$ Laboratoire Dynamique de la Biodiversité, Université \\ P. Sabatier - Toulouse III, UMR CNRS 5172, 31062 Toulouse Cedex 09, \\ France: ${ }^{2}$ Centre de Biologie et de Gestion des Populations (CBGP), \\ UMR INRA-IRD-SupAgro-CIRAD, Institut National de la Recherche \\ Agronomique, Campus International de Baillarguet, 34988 \\ Montferrier/Lez, France
}

\begin{abstract}
Changes in host preferences are thought to be a major source of genetic divergence between phytophagous insect taxa. In western Europe, two sympatric taxa, O. nubilalis (the European corn borer) and O. scapulalis, feed mainly on maize and hop or mugwort, respectively. These two species may have diverged without geographic isolation after a host shift of ancestral populations onto maize or another cultivated species (e.g. sorghum). A previous study using inbred laboratory strains revealed that the two species differ in their oviposition choices in maize-mugwort tests. We sampled four natural populations in France (two of each taxon) and tested their oviposition behaviour toward four of their main host plant species: maize, sorghum, mugwort and hop. O. nubilalis females showed a very high preference for laying their eggmasses on maize, whereas $O$. scapulalis females displayed a more balanced range of preferences. O. nubilalis females were attracted slightly to sorghum, suggesting that this plant is an accidental, rather than a regular and ancestral host plant of $O$. nubilalis. One important result arising from this study is the significant proportion of eggs laid by both Ostrinia species on hop. This may explain why some stands of hop are sometimes not only infested by $O$. scapulalis but also by $O$. nubilalis larvae, a situation preventing assortative mating based on microallopatry. Hence, further studies must be conducted to see whether the host preference in the genus Ostrinia might be linked to assortative mating by a mechanism that is not mediated by the host plant.
\end{abstract}

Keywords: sympatric speciation, ecological speciation, Ostrinia nubilalis, Ostrinia scapulalis, European corn borer, host race, host preference

\section{Introduction}

Host plant choice profoundly shapes the evolution of phytophagous insect taxa. Indeed, comparisons of plant and

*Author for correspondence:

Fax: + 33492386401

E-mail: thibaut.malausa@sophia.inra.fr insect phylogenies suggest that the diversification of vascular plants played a key role in the unprecedented diversification that resulted in insects, most of which are phytophagous, being by far the most species-rich order of multicellular organisms nowadays (Mitter et al., 1988; Ward et al., 2003). Most phytophagous insects feed on only one or a small number of plant species; and many apparently polyphagous taxa have, upon closer examination, been found to be divided into host races or sibling species, i.e. 
into sympatric, partially interfertile but genetically differentiated taxa that use different host plants (Drès \& Mallet, 2002). The fact that such taxa might represent different steps of ecological and sympatric speciation (Schluter, 2001; Via, 2001; Rundle \& Nosil, 2005) has fostered interest for the mechanisms that initiate, maintain or enhance their genetic differentiation (Funk et al., 2002).

Host preference plays a central role in such differentiation by being or becoming associated with traits involved in host performance and/or in assortative mating (Bush, 1975, 1994; Berlocher \& Feder, 2002; Drès \& Mallet, 2002; Rundle \& Nosil, 2005). Association with host performance traits (i.e. traits involved in the ability to survive, grow and mature on a given plant species) favours divergent selection because it ensures that offspring of groups that have undergone different selection pressures are in turn exposed to different selection pressures similar to those experienced by their respective parents. This enables natural selection to steadily act over successive generations, on a consistent set of traits contributing to host adaptation. In addition, host preference can be, or become, associated with the second major ingredient of ecological speciation: reproductive isolation. Such isolation can be the 'by-product' of the two lineages adapting to their respective hosts' spatial distribution or phenology and, therefore, mating in different places or different times; or it can be determined by loci not involved in host adaptation, but happening to be genetically linked to host preference loci.

Strong host preferences have been reported in most of the extensively documented host races: Rhagoletis pomonella (Prokopy et al., 1988; Feder et al., 1994), Eurosta solidaginis (Craig et al., 1993, 2001), Zeiraphera diniana (Bovey \& Maksymov, 1959; Emelianov et al., 2001, 2003), or Acyrtosiphon pisum (Via \& Hawthorne, 2002), all of which have a small (2-4) number of host plants. Most attributes of taxa diverging mainly under ecological selective pressures have also been documented recently in the genus Ostrinia (Lepidoptera: Crambidae). This genus has the interesting property of being extremely polyphagous, e.g. more than 220 host plant species belonging to more than 40 different families for the European corn borer (ECB), Ostrinia nubilalis Hübner (review in Ponsard et al., 2004). Another interesting feature in this genus is the presence of several reproductively isolated taxa infesting maize on the one hand and various host plants on the other hand (Frolov et al., 2007). Among those taxa, two putative sibling species, $O$. scapulalis and $O$. nubilalis, are found, with various degrees of sympatry, from western to central Eurasia (Frolov et al., 2007). O. scapulalis feeds mainly on hop (Humulus sp.), hemp (Cannabis sativa) and mugwort (Artemisia sp.), while O. nubilalis feeds mainly on maize and a set of other plants (e.g. Sorghum sp., Panicum sp.). These two sibling species provide a suitable model to study the role of host preferences over the process of speciation.

Host preferences of Ostrinia populations had been studied first in eastern Europe, notably in the former Soviet Union. Vilkova and Frolov (1978) and Frolov (1991) showed that $O$. nubilalis are more attracted by maize than by hemp, whereas O. scapulalis display the opposite trend. Nagy (1976) also reported that Ostrinia females collected at larval stage on hemp (presumably O. scapulalis) preferred laying their eggmasses on hemp rather than on sorghum, millet, mugwort or maize. Conversely, he found no significant oviposition preference for females collected on maize.
Manojlovic (1984) observed that, among 16 Ostrinia host plants growing together, maize was consistently preferred over the other 15 host plants, including hop and mugwort. In France, host preferences of the two sibling species have been studied by Bethenod et al. (2005). This study, however, used laboratory strains that were highly inbred and tested oviposition preferences toward only two host plant species, maize and mugwort.

At least three questions on host preferences in the genus Ostrinia still need to be addressed. First, do natural populations in France display the same oviposition choices for maize and mugwort as the inbred strains used by Bethenod et al. (2005)? Second, what is the relative attraction of Ostrinia females towards hop, a major host of O. scapulalis in Europe (Martel et al., 2003; Bontemps et al., 2004), which occasionally may be infested by $O$. nubilalis (Malausa et al., 2007a,b)? Third, do O. nubilalis females display a strong attraction towards sorghum? Indeed, since the divergence between the two Ostrinia species is probably older than the introduction of maize into Europe (Malausa et al., 2007a), this host plant could be the ancestral host plant on which Ostrinia populations fed before their shift to maize.

In this study, we further studied the oviposition behaviour of the two Ostrinia sibling species. We used two natural populations per species and tested their oviposition choices when exposed to two-by-two combinations of four common Ostrinia host plant species: maize, mugwort, hop and sorghum. Oviposition was recorded as the number of eggmasses and the number of eggs laid on each plant. Plant size was recorded to control for differences in total plant surface available for oviposition. Data were analyzed in order to determine whether the two sibling Ostrinia species displayed consistent differences in host preference and oviposition behaviour.

\section{Material and methods \\ Sampling and plant preparation}

Four Ostrinia sp. populations were sampled during the winter 2004-2005, two (Muret and Viabugn) from maize and two (Amiens and Lille) from mugwort (fig. 1). These collection sites are located in France, in areas where O. nubilalis and O. scapulalis occur at different degrees of sympatry. Indeed, whereas populations of these two sibling species co-occur at substantial densities around Paris (e.g. Viabugn and Amiens), populations of O. nubilalis and O. scapulalis are very scarce in northern (around Lille) and southern (around Toulouse) France, respectively. Collecting individuals in the latter areas, in sites where no host plant of the other species was observed over several kilometres, insured that pure populations of each species were collected. Based on the results of Bourguet et al. (2000), Martel et al. (2003), Thomas et al. (2003), Pélozuelo et al. (2004), Bontemps et al. (2004) and Malausa et al. (2005), we hypothesized that populations collected on mugwort and maize in these areas consisted exclusively of $O$. nubilalis and $O$. scapulalis individuals, respectively. Indeed, these authors found that, all over France, Ostrinia females exclusively use the E (when originating from mugwort) or the $\mathrm{Z}$ (when originating from maize) sex pheromone blends, suggesting that these two host plants house pure populations of $O$. nubilalis (on maize) and O. scapulalis (on mugwort). For each population, $\sim 1200$ diapausing larvae were collected and maintained at $4^{\circ} \mathrm{C}$ 


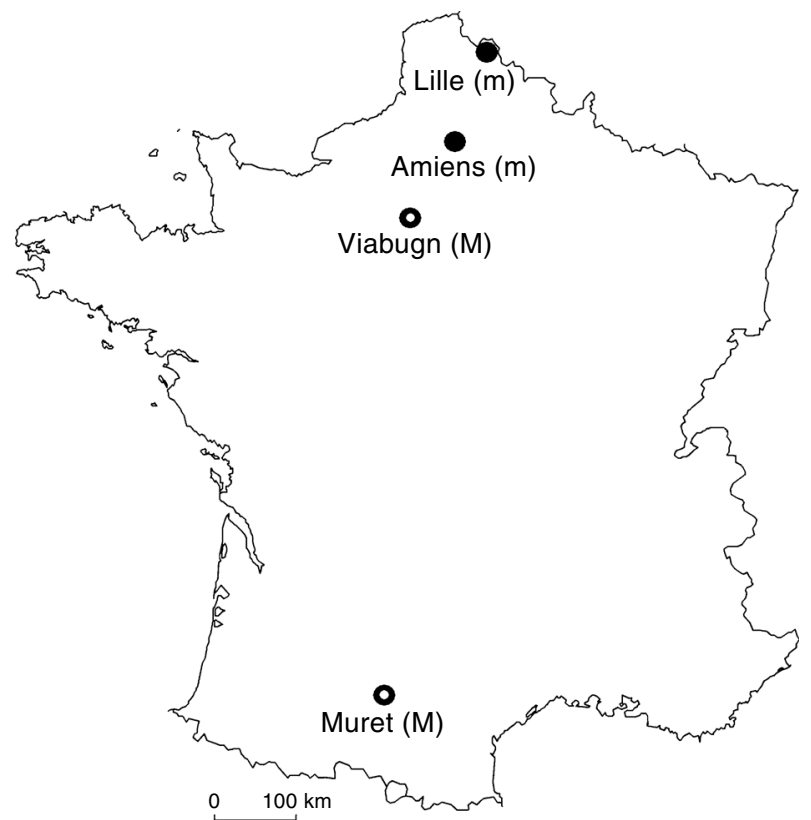

Fig. 1. Sampling sites of the two Ostrinia sibling species. M, populations of $O$. nubilalis collected on maize; $\mathrm{m}$, populations of O. scapulalis collected on mugwort.

during the winter. Adult moths were obtained by breaking diapause, i.e. by placing the larvae at $\sim 25^{\circ} \mathrm{C}$ in June or July 2005.

Four host plant species were used in our experiments: mugwort, maize, sorghum and hop. Mugwort roots were collected in northern France during the winter 2004-2005 and maintained at $5^{\circ} \mathrm{C}$ until they were placed at external temperature during spring and summer 2005 and plants were grown from them. From May to August, 100 maize (var. Cecilia) and sorghum (var. Burgho) commercial seeds were sown each week in seven litre pots providing an adequate number of plants for testing. Finally, small hop plants were provided by A. Weissenberger (SRPV, Alsace, France) over May, June and July 2005 and grown locally until they were used.

\section{Oviposition preference test protocol}

Twenty five $1 \times 1 \times 1.4 \mathrm{~m}(\mathrm{~L} \times \mathrm{W} \times \mathrm{H})$ wood cages, entirely covered by mosquito nets, were set up on a lawn of the Toulouse Rangueil University Campus. Each test consisted in releasing six virgin individuals (three males and three females) into a cage containing a combination of two host plant species. Each host plant combination was tested in pairwise tests replicated 6-8 times. For each test, four plants (two per species) were placed into the cage; the two plants of the same species standing diagonally from each other. Adult moths were released at dusk and removed in the morning of the fifth day. All plants were then taken outside the cages and eggmasses and eggs laid on each plant were carefully counted.

Each maize, sorghum or hop plant was used only once. As the number of mugwort plants was limited, each plant of this species was used twice. Before its second use, the plant was cleared of any eggmasses and left outdoor for at least two days before its second use. It received 'blanket' watering through a hose at least once a day, if not twice, as the weather was extremely hot. This might have reduced the possible influence of putative marking pheromones. As phenology can have a significant impact on host plants attraction (Patch, 1942; Derridj et al., 1989; Lupoli et al., 1990; Spangler \& Calvin, 2000), experiments were performed using plants at similar development stages. Maize, sorghum and hop plants were 5, 5-6 and 5-7 weeks old, respectively. The exact age of mugwort plants could not be estimated, but all plants were $70-110 \mathrm{~cm}$ high. Finally, host plant combinations were tested in random order over the course of the experiment in order to avoid any relation between time period and host plant species involved in the tests.

For each plant, the total surface available for oviposition was estimated by the following protocol. For each host species, a set of 20-30 plants was randomly chosen. For each plant, all leaves were scanned and their overall surface was estimated by automatically counting the pixels of the resulting pictures using the ImageJ 1.33 u software (Abramoff et al., 2004). In addition, the dry weight of the leaf set corresponding to each of a sub-sample of 20-30 plants was recorded for each host species. The XLSTAT 2006.3 program was used to test the fit of linear regression models with leaf dry weight and overall leaf surface as the explanatory and dependant variables, respectively. The regression coefficient of determination $\left(r^{2}\right)$ between dry weight and leaf surface were $0.80(n=30), 0.47(n=29)$ and $0.89(n=28)$ for maize, hop and sorghum, respectively. Corresponding mean absolute percentage errors (MAPE) of leaf surface estimates were $13.5 \%, 15.6 \%$ and $10.9 \%$, respectively. For these three host plants, we therefore used the regression equation to infer the overall leaf surface of each plant used in the experiment from its dry weight. For mugwort, $r^{2}$ was lower, $0.33(n=23)$, and the mean absolute percentage error was $34.7 \%$, so that we decided to scan all plants used in the experiments rather than inferring their leaf surfaces from their dry weights. The total plant surface available for oviposition was the sum of the overall leaf surface and the stem surface (circumference at mid-height $\times$ plant height), except for hop, where the stems were very thin and therefore of negligible surface when compared to leaves $(<5 \%)$. The number of eggmasses on a plant species $\mathrm{X}$ after correction with plant surface ratios $($ Ecorr X) was calculated using equation (1).

$$
E \operatorname{corr} X=\frac{S_{m}}{S x} \times E x \times\left(\frac{E_{1}+E_{2}}{\frac{S_{m}}{S_{1}} \times E_{1}+\frac{S_{m}}{S_{2}} \times E_{2}}\right)
$$

where $S_{m}$ is the mean surface of both species of plants, $S_{1}$ and $S_{2}$ are the surfaces of plants from species 1 and species 2, respectively, and $E_{1}$ and $E_{2}$ are the uncorrected number of eggmasses on plant species 1 and 2 , respectively.

\section{Data analysis}

Proportions of eggmasses laid on each host plant

The proportion of eggmasses, rather than the proportion of eggs, was used as an indicator of host preference. Indeed, both Ostrinia species lay their eggs in clusters of $\sim 20$ eggs, so that individual eggs cannot be considered as the results of repeated, independent choices. For each host plant combination, we used the GENMOD procedure of SAS (1989) with a 
binomial distribution of the residuals and a type 3 analysis to test for the influence of the factors 'Ostrinia species' and 'population (Ostrinia species)' on the average proportions of eggmasses (corrected or not by the leaf surfaces of the plants) laid on the two host plants available in the cage. A Chi-square test was used to determine whether these proportions were significantly different from 0.5 , the proportion expected if females randomly oviposited on the two available host plants.

\section{Size of the eggmasses}

Differences between populations and sibling species were further examined by comparing the size of their eggmasses, measured as the number of eggs per eggmass. This analysis was performed on a dataset in which the experimental unit was the host plant individual, i.e. one of the four plants introduced into the cages. We used the MIXED procedure of SAS with repeated measures to test for the influence of the factors 'Ostrinia species', 'population (Ostrinia species)' and 'plant species', as well as the interactions 'Ostrinia species' $\times$ 'plant species' and 'population (Ostrinia species)' $\times$ 'plant species', on the variable 'number of eggs per eggmass'. 'Experiment number' (from 1 to 192) was considered as a random effect in the model. Each eggmass laid by females on a plant was treated as a repeated measure of the number of eggs per eggmass on the corresponding plant. The chosen covariance structure in the REPEATED statement was 'compound symmetry' (option '/type $=\mathrm{CS}^{\prime}$ ). Each plant introduced into a given cage was, thus, considered as subject in the REPEATED statement of the mixed procedure. Comparisons between sibling species and/or populations were performed with the LSMEANS statement and the PDIFF option.

\section{Total number of eggs laid}

We examined possible differences in the total number of eggs laid in each host plant combination, i.e. the total number of eggs of all eggmasses collected on the four plants of any given cage. The total number of eggs rather than number of eggmasses was used because we considered that it better estimated the energetic investment of females in oviposition on each plant. Since differences in early female mortality could bias the results by affecting the number of eggs laid over the duration of the experiments, this analysis was carried out on a dataset excluding replicates in which less than two out of three females were alive at the end of the experiment. The GENMOD procedure of SAS, with a normal distribution of the residuals, was used to test for the influence of factors 'Ostrinia species', 'population (Ostrinia species)', and 'plant species combination' on the total number of eggs laid by females. In order to determine whether the plant surface influenced the number of eggs laid, we added 'plant surface' as a covariable to the model. The LSMEANS option was used to compare the total number of eggs among all combinations of the three explanatory variables. Bonferroni corrections were applied to all pairwise tests.

\section{Results}

\section{Proportions of eggmasses laid on each host plant}

In all but one combination of host plants, the proportion of eggmasses laid on each plant was strongly influenced by the factor 'Ostrinia species', whether or not this proportion was corrected by the available plant surface $\left(\mathrm{Chi}^{2}>15.64\right.$, $\mathrm{df}=1, P<10^{-3}$ for all tests except for the hop-sorghum combination where $\mathrm{Chi}^{2}=4.22$, $\mathrm{df}=1, P=0.040$ when the proportion was not corrected by plant surface). The only plant combination for which the proportion of eggmasses laid on each host plant was not influenced by the 'Ostrinia species' factor was maize-sorghum $\left(\mathrm{Chi}^{2}=0.31, \mathrm{df}=1, P=\right.$ 0.577 and $\mathrm{Chi}^{2}=1.17, \mathrm{df}=1, P=0.279$ with uncorrected and corrected proportions, respectively). A significant influence of the factor 'population (Ostrinia species)' was detected in two plant combinations: mugwort-hop $\left(\mathrm{Chi}^{2}>20.83, \mathrm{df}=2\right.$, $P<10^{-3}$ with both corrected or uncorrected proportions); and mugwort-sorghum $\left(\mathrm{Chi}^{2}=9.92, \mathrm{df}=2, P=0.007\right.$ with corrected proportions but $\mathrm{Chi}^{2}=1.01, \mathrm{df}=2, P=0.604$ with uncorrected proportions). LSMEANS pairwise comparisons revealed that the 'population (Ostrinia species)' factor only had an influence on the proportion of eggmasses laid on each plant in O. nubilalis.

The proportions, whether or not corrected by the proportion of available plant surfaces, of eggmasses laid by each population on the two types of plants used in the different combinations are given in table 1 . When cages contained both maize and mugwort, the two sibling species displayed antagonistic preferences; O. nubilalis females laid $>95 \%$ of their eggmasses on maize, whereas O. scapulalis females laid $61 \%$ (or $>70 \%$ after correction) of their eggmasses on mugwort. The preference of both Ostrinia species was high enough to significantly reject the null hypothesis that females displayed no oviposition preference, i.e. that they laid $50 \%$ of their eggmasses on each plant $\left(P<10^{-3}\right.$ for all populations). Although less marked, results for the maize-hop combination displayed the same trend; O. nubilalis females laid between 75 and $85 \%$ of their eggmasses on maize, these proportions being significantly $\left(P<10^{-3}\right)$ higher than $50 \%$ for both populations. Although $O$. scapulalis females were still less attracted by maize than by hop, the proportions of eggmasses laid on each plant did not significantly differ from $50 \%(P=0.359$ and $P=0.188$ for Lille and Amiens, respectively), unless they were corrected by the relative plant surface available for oviposition $\left(P<10^{-3}\right.$ for both populations).

When given the choice between maize and sorghum, all populations strongly, if not exclusively, chose to oviposit on maize, resulting once again in the rejection of the $50 \%$ null hypothesis $\left(P<10^{-3}\right.$ for all populations for both corrected and uncorrected proportions). In cages containing hop and mugwort, females of both Ostrinia species showed a marked preference for hop; whether corrected or not, the proportion of eggmasses laid on this plant was always significantly higher than $50 \%\left(P<10^{-3}\right)$ and varied from 75 to $97 \%$. The mugwort-sorghum combination showed that $O$. scapulalis had a clear and substantial preference for mugwort, as the proportions (corrected or not) were always $>75 \%$ and significantly different from $50 \%\left(P<10^{-3}\right)$. Conversely, this combination was the only one not revealing any clear preference in $O$. nubilalis females. The proportions of eggmasses laid on these two plants were not significantly different from 50\% ( $P>0.094)$, except for the Muret population and only after taking available plant surface into consideration $(P=0.049)$. The last plant combination (hop-sorghum) again revealed very strong preferences. Both O. nubilalis and O. scapulalis preferred to oviposit on hop; the departure from $50 \%$ was highly significant for the four Ostrinia populations $\left(P<10^{-3}\right)$. This trend was slightly 
Table 1. Proportions of eggmasses (corrected or not by the relative amount of available plant surface) and mean numbers of eggs laid during tests involving the various host plant combinations. The $95 \%$ confidence intervals (CI) were calculated using the modified Wald method (Agresti \& Coull, 1998).

\begin{tabular}{|c|c|c|c|c|c|c|c|c|c|}
\hline \multirow{2}{*}{\multicolumn{2}{|c|}{ Host plant combination }} & \multirow{3}{*}{$\begin{array}{l}\text { Ostrinia } \\
\text { species }\end{array}$} & \multirow[t]{3}{*}{ Population } & \multicolumn{4}{|c|}{ Proportion of eggmasses laid on host plant \#1 } & & \\
\hline & & & & \multicolumn{2}{|c|}{$\begin{array}{l}\text { Uncorrected by available } \\
\text { plant surface }\end{array}$} & \multicolumn{2}{|c|}{$\begin{array}{l}\text { Corrected by available } \\
\text { plant surface }\end{array}$} & \multicolumn{2}{|c|}{ Number of eggs } \\
\hline Host plant \#1 & Host plant \#2 & & & Mean & $95 \% \mathrm{CI}$ & Mean & $95 \% \mathrm{CI}$ & Mean & SD \\
\hline Maize & Mugwort & $\begin{array}{l}\text { O. scapulalis } \\
\text { O. nubilalis }\end{array}$ & $\begin{array}{l}\text { Lille } \\
\text { Amiens } \\
\text { Muret } \\
\text { Viabugn }\end{array}$ & $\begin{array}{l}0.39^{*} \\
0.39^{*} \\
0.98^{*} \\
0.98^{*}\end{array}$ & $\begin{array}{l}0.32-0.46 \\
0.32-0.46 \\
0.96-0.99 \\
0.96-0.99\end{array}$ & $\begin{array}{l}0.26^{*} \\
0.27^{*} \\
0.97^{*} \\
0.95^{*}\end{array}$ & $\begin{array}{l}0.20-0.33 \\
0.21-0.33 \\
0.95-0.98 \\
0.92-0.97\end{array}$ & $\begin{array}{r}590 \\
710 \\
1,004 \\
827\end{array}$ & $\begin{array}{l}171.3 \\
310.7 \\
293.4 \\
211.7\end{array}$ \\
\hline Maize & Hop & $\begin{array}{l}\text { O. scapulalis } \\
\text { O. nubilalis }\end{array}$ & $\begin{array}{l}\text { Lille } \\
\text { Amiens } \\
\text { Muret } \\
\text { Viabugn }\end{array}$ & $\begin{array}{l}0.47 \\
0.45 \\
0.85^{*} \\
0.80^{*}\end{array}$ & $\begin{array}{l}0.40-0.54 \\
0.38-0.52 \\
0.81-0.89 \\
0.75-0.83\end{array}$ & $\begin{array}{l}0.36^{*} \\
0.35^{*} \\
0.80^{*} \\
0.75^{*}\end{array}$ & $\begin{array}{l}0.30-0.43 \\
0.28-0.43 \\
0.76-0.84 \\
0.70-0.81\end{array}$ & $\begin{array}{l}591 \\
417 \\
713 \\
756\end{array}$ & $\begin{array}{l}137.8 \\
192.0 \\
204.9 \\
193.0\end{array}$ \\
\hline Maize & Sorghum & $\begin{array}{l}\text { O. scapulalis } \\
\text { O. nubilalis }\end{array}$ & $\begin{array}{l}\text { Lille } \\
\text { Amiens } \\
\text { Muret } \\
\text { Viabugn }\end{array}$ & $\begin{array}{l}0.96^{*} \\
0.96^{*} \\
0.96^{*} \\
0.97^{*}\end{array}$ & $\begin{array}{l}0.91-0.98 \\
0.91-0.98 \\
0.94-0.98 \\
0.93-0.99\end{array}$ & $\begin{array}{l}0.91^{*} \\
0.92^{*} \\
0.92^{*} \\
0.95^{*}\end{array}$ & $\begin{array}{l}0.85-0.94 \\
0.86-0.96 \\
0.89-0.95 \\
0.90-0.98\end{array}$ & $\begin{array}{l}420 \\
652 \\
973 \\
469\end{array}$ & $\begin{array}{l}277.5 \\
120.2 \\
467.1 \\
177.5\end{array}$ \\
\hline Mugwort & Hop & $\begin{array}{l}\text { O. scapulalis } \\
\text { O. nubilalis }\end{array}$ & $\begin{array}{l}\text { Lille } \\
\text { Amiens } \\
\text { Muret } \\
\text { Viabugn }\end{array}$ & $\begin{array}{l}0.18^{*} \\
0.17^{*} \\
0.03^{*} \\
0.13^{*}\end{array}$ & $\begin{array}{l}0.14-0.23 \\
0.13-0.23 \\
0.02-0.06 \\
0.10-0.18\end{array}$ & $\begin{array}{l}0.25^{*} \\
0.21^{*} \\
0.05^{*} \\
0.18^{*}\end{array}$ & $\begin{array}{l}0.20-0.30 \\
0.16-0.26 \\
0.03-0.08 \\
0.14-0.23\end{array}$ & $\begin{array}{l}451 \\
570 \\
686 \\
474\end{array}$ & $\begin{array}{l}206.6 \\
356.2 \\
344.5 \\
378.0\end{array}$ \\
\hline Mugwort & Sorghum & $\begin{array}{l}\text { O. scapulalis } \\
\text { O. nubilalis }\end{array}$ & $\begin{array}{l}\text { Lille } \\
\text { Amiens } \\
\text { Muret } \\
\text { Viabugn }\end{array}$ & $\begin{array}{l}0.83^{*} \\
0.79^{*} \\
0.51 \\
0.53\end{array}$ & $\begin{array}{l}0.78-0.87 \\
0.71-0.85 \\
0.40-0.62 \\
0.41-0.64\end{array}$ & $\begin{array}{l}0.86^{*} \\
0.79^{*} \\
0.39^{*} \\
0.60\end{array}$ & $\begin{array}{l}0.82-0.90 \\
0.71-0.85 \\
0.29-0.50 \\
0.48-0.71\end{array}$ & $\begin{array}{l}739 \\
329 \\
251 \\
205\end{array}$ & $\begin{array}{l}458.2 \\
213.8 \\
182.3 \\
113.0\end{array}$ \\
\hline Hop & Sorghum & $\begin{array}{l}\text { O. scapulalis } \\
\text { O. nubilalis }\end{array}$ & $\begin{array}{l}\text { Lille } \\
\text { Amiens } \\
\text { Muret } \\
\text { Viabugn }\end{array}$ & $\begin{array}{l}0.93^{*} \\
0.91^{*} \\
0.90^{*} \\
0.84^{*}\end{array}$ & $\begin{array}{l}0.87-0.96 \\
0.84-0.96 \\
0.85-0.93 \\
0.78-0.88\end{array}$ & $\begin{array}{l}0.96^{*} \\
0.93^{*} \\
0.84^{*} \\
0.86^{*}\end{array}$ & $\begin{array}{l}0.91-0.98 \\
0.85-0.96 \\
0.78-0.88 \\
0.80-0.90\end{array}$ & $\begin{array}{l}406 \\
364 \\
528 \\
585\end{array}$ & $\begin{array}{r}97.6 \\
199.1 \\
371.0 \\
188.6\end{array}$ \\
\hline
\end{tabular}

* indicates that the proportion was significantly different from $50 \%$. 
Table 2. Mean sizes (mean number of eggs) and standard deviations (SD) of the eggmasses laid by each population of each Ostrinia sibling species on the various host plants.

\begin{tabular}{lllcr}
\hline $\begin{array}{l}\text { Host } \\
\text { plant }\end{array}$ & Sibling species & Population & \multicolumn{2}{c}{$\begin{array}{c}\text { Number of eggs } \\
\text { per eggmass }\end{array}$} \\
\cline { 3 - 4 } Maize & & Mean & SD \\
& & Lille & 23.5 & 1.2 \\
& O. scapulalis & Amiens & 21.8 & 1.3 \\
& O. nubilalis & Muret & 19.0 & 0.9 \\
& & Viabugn & 18.3 & 0.9 \\
Mugwort & O. scapulalis & Lille & 20.6 & 1.2 \\
& & Amiens & 19.8 & 1.3 \\
& O. nubilalis & Muret & 16.5 & 2.0 \\
& & Viabugn & 19.4 & 1.8 \\
Hop & O. scapulalis & Lille & 16.1 & 1.0 \\
& O. nubilalis & Amiens & 15.7 & 1.1 \\
& & Muret & 16.4 & 1.0 \\
Sorghum & O. scapulalis & Viabugn & 16.8 & 2.1 \\
& & Lille & 19.3 & 2.3 \\
& O. nubilalis & Amiens & 19.6 & 1.8 \\
& & Muret & 21.7 & 1.9 \\
\hline
\end{tabular}

stronger in O. scapulalis (with a proportion on hop >90\%) than in $O$. nubilalis (with a proportion on hop varying from 80 to $90 \%$ ).

\section{Size of the eggmasses}

Both 'plant species' and the 'plant species $\times$ Ostrinia species' interaction had a significant effect on the number of eggs per eggmass $\left(F=15.55, \mathrm{df}=3, P<10^{-3}\right.$ and $F=6.68$, $\mathrm{df}=3, P<10^{-3}$, respectively). Conversely, the size of the eggmasses was not influenced by 'Ostrinia species', 'population (Ostrinia species)', or by the 'plant species $\times$ population (Ostrinia species)' interaction $(F=0.12, \mathrm{df}=1, P=0.734 ; F=$ $1.42, \mathrm{df}=2, P=0.241$; and $F=0.77, \mathrm{df}=6, P=0.594$, respectively).

The mean sizes of eggmasses laid by each population on the various host plants are given in table 2 . On average, the eggmasses laid by the females of the two Ostrinia species contained $\sim 20$ eggs. For $O$. nubilalis, these eggmasses were significantly smaller when laid on maize and significantly larger when laid on sorghum $\left(P<10^{-4}\right.$ and $P=0.028$, respectively).

\section{Total number of eggs laid}

'Ostrinia species' $\left(\mathrm{Chi}^{2}=6.02, \mathrm{df}=1, P=0.014\right)$, 'population (Ostrinia species)' $\left(\mathrm{Chi}^{2}=6.09, \mathrm{df}=2, P=0.048\right)$, 'plant species combination' $\left(\mathrm{Chi}^{2}=16.16, \mathrm{df}=5, P=0.006\right)$ and the 'Ostrinia species $\times$ plant species combination' $\left(\mathrm{Chi}^{2}=21.47\right.$, $\mathrm{df}=5, P<10^{-3}$ ) and 'population (Ostrinia species) $\times$ plant species combination' $\left(\mathrm{Chi}^{2}=19.59, \mathrm{df}=10, P=0.033\right)$ interactions all significantly influenced the total number of eggs laid by females. Conversely, no significant effect of the 'plant surface' factor was detected $\left(\mathrm{Chi}^{2}=1.69, \mathrm{df}=1, P=0.193\right)$.

Overall, $O$. nubilalis females produced more eggs than O. scapulalis females. The total number of eggs laid by each population per plant combination is given in table 1 . It ranged from 205 (for the Viabugn population in the mugwort-sorghum combination) to 1004 (for the Muret population in the maize-mugwort combination). Bonferroni-corrected pairwise comparisons (results not shown) revealed that (pooling Amiens and Lille populations) O. scapulalis displayed no significant differences of the mean number of eggs laid on the various plant combinations. For O. nubilalis (pooling Muret and Viabugn populations), 5 out of 15 pairwise comparisons revealed differences between plant combinations, four of which included maize as one of the two plants.

\section{Discussion}

Both $O$. nubilalis populations showed a high preference for maize (75-98\%), while populations of O. scapulalis showed a significant preference (61-83\%) for hop and mugwort over maize and sorghum. These results are consistent with those reported by Nagy (1976), Vilkova \& Frolov (1978), Manojlovic (1984), Savinelli et al. (1988), Frolov (1991) and Bethenod et al. (2005) on other European populations or strains of Ostrinia. Hence, populations of O. nubilalis and O. scapulalis (sensu Frolov et al., 2007) display consistent host preferences in France and eastern Europe. Overall, results obtained on oviposition in the genus Ostrinia point to a high preference of $O$. nubilalis for maize and a more balanced range of preferences for $O$. scapulalis, the latter species being strongly attracted by mugwort, hemp and hop. It is noteworthy that these preferences are of the same order of magnitude (70-100\% of eggmasses on native hosts) as those recorded between host races and sibling species of other phytophagous insects: Nilaparvata lugens (Sezer \& Butlin, 1998), E. solidaginis (Craig et al., 2001), Galerucella nymphaeae (Pappers et al., 2002) and Z. diniana (Bovey \& Maksymov, 1959). The magnitude of these preferences was also similar to those recorded by Prokopy et al. (1988) on R. pomonella in non-choice experiments.

Because sorghum and maize share a very similar morphology and a C4-type photosynthesis and because sorghum has been repeatedly recorded as an ECB host plant in several parts of the world (the former Soviet Union (Frolov et al., 
1995); North America (Painter \& Weibel, 1951; Atkins et al., 1983; Guthrie et al., 1985); Hungary (Nagy, 1976); the former Yugoslavia (Manojlovic, 1984); and France (Leniaud et al., 2006)), sorghum would logically appear as a good candidate for ancestral host of $O$. nubilalis. However, our results clearly show that females of both Ostrinia species were attracted slightly to sorghum. Hence, unless its attractivity changed over time, this crop would seem to be an accidental, rather than a regular and ancestral host plant of $O$. nubilalis.

Although, for both $O$. nubilalis and O. scapulalis, the oviposition preferences we found between maize and mugwort were similar to what we expected, results for hop were quite surprising for both species. The first intriguing result is the marked preference of $O$. scapulalis for hop over mugwort, which ranged from 75 to $83 \%$. Indeed, in northern France, mugwort is usually more infested than hop, even when growing in sympatry at a scale $<100 \mathrm{~m}$ (TM, DB and SP, personal observation). The second surprising result is that O. nubilalis does also oviposit readily on hop. This might explain why some diapausing larvae collected on hop in southern France are genetically assigned to $O$. nubilalis (Malausa et al., 2007b). On the other hand, a substantial attraction of $O$. nubilalis females towards hop is hardly compatible with the low level of infestations found in northern France. In that area, most diapausing larvae collected on hop are genetically assigned to O. scapulalis (Malausa et al., 2007b). One possibility is that larvae of $O$. nubilalis have a much lower survival rate on hop than larvae O. scapulalis do, i.e. although $O$. nubilalis females lay a substantial proportion of their eggmasses on hop only a low percentage of the larvae reach the diapausing stage. However, this would contradict the data presented in Manojlovic et al. (1984), suggesting that the survival of ECB larvae tends to be higher, not lower, on hop than on maize and on mugwort. A second explanation is that the attraction of O. nubilalis females towards hop was higher in our experiment than what really happens in field conditions. Indeed, our experimental design enabled us to examine short-range, but not long-range, responses of Ostrinia females to hostplant features. Plant volatiles are known to play an active role in attracting ECB females (Schurr \& Holdaway, 1970; Cantelo \& Jacobson, 1979; Lupoli et al., 1990; Binder et al., 1995), and their effects may not have been fully visible at the scale of our experiment. This would suggest that the shortrange attractivity of hop for Ostrinia is high (in our experiment, it ranked first for O. scapulalis and was second only to maize for $O$. nubilalis) and that the reason for its low infestation in the field is due rather to a relative lack of longrange attractivity.

Unlike in R. pomonella (Feder et al., 1994) or Z. diniana (Emelianov et al., 2001, 2003), no mechanism of assortative mating directly induced by adult host-preference has been established clearly so far in the genus Ostrinia. Yet host preference might result in habitat isolation and microallopatry between the two Ostrinia sibling species since mugwort, hop and maize do not always grow in fine-scale sympatry and pre-mating dispersal can be limited, at least for O. nubilalis (Dalecky et al., 2006). However, when stands of hop are infested by both taxa, the emergence of adults in the same place prevents any assortative matings based on microallopatry. Moreover, ECBs are able to fly over several hundred meters (Hunt et al., 2001; Showers et al., 2001; Qureshi et al., 2005) and do not mate exclusively on their host plants but also in dense foxtail grass and other herbaceous, non-host-plant patches (Showers et al., 1976). In addition, allochrony caused by developmental lags between the different plants seems limited (Thomas et al., 2003) or absent (Malausa et al., 2005), at least in the surroundings of Paris. If further studies were to confirm that the host preference in the genus Ostrinia is linked to assortative mating by a mechanism that is not mediated by the host plant, comparative studies with host races or sibling species, where this appears to be the case, could provide interesting insights.

\section{Acknowledgements}

We thank the anonymous people who destroyed only two cages, leaving a sufficient number of them to complete this experiment; Alain Ferrier from 'La Toulousaine des Céréales' and Alain Weissenberger from 'SRPV Alsace'; Laurent Crespin for helpful advice during data analysis; Claudine, Robert and Vincent Malausa for their help in the snowy plain of Viabugn. The financial support of this study was provided by the IFB, AO Biodiversité et Changement Global; the CNRS, AO Impact des Biotechnologies sur les Agrosystèmes; the ACI-FNS 'Ecco', Ecosphère Continentale: Processus et Modélisation; and the EU project 'ProBenBt'.

\section{References}

Abramoff, M., Magelhaes, P. \& Ram, S. (2004) Image Processing with ImageJ. Biophotonics International 11, 36-42.

Agresti, A. \& Coull, B.A. (1998) Approximate is better than 'exact' for interval estimation of binomial proportions. American Statistician 52, 119-126.

Atkins, R.E., Guthrie, W.D., Ross, W.M. \& Kindler, S.D. (1983) Investigations of host-plant resistance to the European corn borer in sorghum. Iowa State Journal of Research 57, 275-292.

Berlocher, S. \& Feder, J. (2002) Sympatric speciation in phytophagous insects: moving beyond controversy? Annual Review of Entomology 47, 773-815.

Bethenod, M.-T., Thomas, Y., Rousset, F., Frérot, B., Pélozuelo, L., Genestier, G. \& Bourguet, D. (2005) Genetic isolation between two sympatric host plant races of the European corn borer, Ostrinia nubilalis Hübner. II. Assortative mating and host plant preferences for oviposition. Heredity 94, 264270.

Binder, B., Robbins, J. \& Wilson, R. (1995) Chemically mediated ovipositional behaviors of the European corn borer, Ostrinia nubilalis (Lepidoptera: Pyralidae). Journal of Chemical Ecology 21, 1315-1327.

Bontemps, A., Bourguet, D., Pélozuelo, L., Bethenod, M.-T. \& Ponsard, S. (2004) Managing the evolution of Bacillus thuringiensis resistance in natural populations of the European corn borer, Ostrinia nubilalis: host plant, host race and pherotype of adult males at aggregation sites. Proceedings of the Royal Society of London Series B 271, 21792185.

Bourguet, D., Bethenod, M.-T., Trouvé, C. \& Viard, F. (2000) Host-plant diversity of the European corn borer Ostrinia nubilalis: what value for sustainable transgenic insecticidal Bt maize? Proceedings of the Royal Society of London Series B 267, 1177-1184.

Bovey, P. \& Maksymov, J. (1959) Le problème des races biologiques chez la Tordeuse grise du Mélèze Zeiraphera griseana (Hb.). Vierteljahresschrift der Naturforschenden Gesellschaft in Zürich 104, 264-274. 
Bush, G. (1975) Modes of animal speciation. Annual Review of Ecology and Systematics 6, 339-364.

Bush, G. (1994) Sympatric speciation in animals: new wine in old bottles. Trends in Ecology \& Evolution 9, 285-288.

Cantelo, W. \& Jacobson, M. (1979) Corn silks volatiles attract many pests species of moths. Journal of Environmental Science and Health 14, 695-707.

Craig, T.P., Itami, J.K., Abrahamson, W.G. \& Horner, J.D. (1993) Behavioral evidence for host-race formation in Eurosta solidaginis. Evolution 47, 1696-1710.

Craig, T.P., Horner, J.D. \& Itami, J.K. (2001) Genetics, experience, and host-plant preference in Eurosta solidaginis: Implications for host shifts and speciation. Evolution 55, 773-782.

Dalecky, A., Ponsard, S., Bailey, R.I., Pelissier, C. \& Bourguet, D. (2006) Resistance evolution to Bt crops: Predispersal mating of European corn borers. PLoS Biology 4, 1048-1057.

Derridj, S., Gregoire, V., Boutin, J. \& Fiala, V. (1989) Plant growth stages in the interspecific oviposition preference of the European corn borer and relations with chemicals present on leaf surfaces. Entomologia Experimentalis et Applicata 53, 267-276.

Drès, M. \& Mallet, J. (2002) Host races in plant-feeding insects and their importance in sympatric speciation. Philosophical Transactions of the Royal Society of London, Series B 357, 471492.

Emelianov, I., Dres, M., Baltensweiler, W. \& Mallet, J. (2001) Host-induced assortative mating in host races of the larch budmoth. Evolution 55, 2002-2010.

Emelianov, I., Simpson, F., Narang, P. \& Mallet, J. (2003) Host choice promotes reproductive isolation between host races of the larch budmoth Zeiraphera diniana. Journal of Evolutionary Biology 16, 208-218.

Feder, J., Opp, S., Wlazlo, B., Reynolds, K., Go, W. \& Spisak, S. (1994) Host fidelity is an effective premating barrier between sympatric races of the apple maggot fly. Proceedings of the National Academy of Sciences, USA 91, 7990-7994.

Frolov, A. (1991) Analysis of trophic relations of the European corn borer and brush-leg borer (Lepidoptera, Pyraustidae) in the border of the maize field weeded with mugwort. Ekologiya 3, 63-69.

Frolov, A.N., Dyatlova, K.D. \& Andriyash, N.V. (1995) European corn borer on sorghum in the Krasnodar region. Kukuruza i Sorgo 2, 5-6.

Frolov, A.N., Bourguet, D. \& Ponsard, S. (2007) Reconsidering the taxomony of several Ostrinia species in the light of reproductive isolation: a tale for Ernst Mayr. Biological Journal of the Linnean Society 91, 49-72.

Funk, D.J., Filchak, K.E. \& Feder, J.L. (2002) Herbivorous insects: model systems for the comparative study of speciation ecology. Genetica 116, 251-267.

Guthrie, W.D., Dharmalingam, S., Jarvis, J.L., Kindler, D., Atkins, R.E., Tseng, C.T. \& Zhou, D. (1985) Resistance of sorghum genotypes to leaf feeding by first-generation European corn borer larvae compared with maize genotypes. Journal of Agricultural Entomology 2, 175-184.

Hunt, T.E., Higley, L.G., Witkowski, J.F., Young, L.J. \& Hellmich, R.L. (2001) Dispersal of adult European corn borer (Lepidoptera: Crambidae) within and proximal to irrigated and non-irrigated corn. Journal of Economic Entomology 94, 1369-1377.

Leniaud, L., Audiot, P., Bourguet, D., Frerot, B., Genestier, G., Lee, S.F., Malausa, T., Le Pallec, A.H., Souqual, M.C. \& Ponsard, S. (2006) Genetic structure of European and
Mediterranean maize borer populations on several wild and cultivated host plants. Entomologia Experimentalis et Applicata 120, 51-62.

Lupoli, R., Marion-Poll, F., Pham-Delègue, M. \& Masson, C. (1990) Influence of maize leaf volatiles on the oviposition preferences of Ostrinia nubilalis (Lepidoptera: Pyralidae). Comptes Rendus de l'Academie des Sciences, Paris 311, 225-230.

Malausa, T., Bethenod, M.T., Bontemps, A., Bourguet, D., Cornuet, J.M. \& Ponsard, S. (2005) Assortative mating in sympatric host races of the European corn borer. Science 308, 258-260.

Malausa, T., Leniaud, L., Martin, J.F., Audiot, P., Bourguet, D., Ponsard, S., Lee, S.F., Harrison, R.G. \& Dopman, E. (2007a) Molecular differentiation at several nuclear loci in French host races of the European corn borer (Ostrinia nubilalis). Genetics 176, 2343-2355.

Malausa, T., Dalecky, A., Ponsard, S., Audiot, P., Chaval, Y., Streiff, R. \& Bourguet, D. (2007b) Genetic structure and gene flow in French populations of two Ostrinia taxa: Host races or sibling species? Molecular Ecology 16, 42104222.

Manojlovic, B. (1984) The possibility of survival of the larvae of the European corn borer (Ostrinia nubilalis Hbn., Lep. Pyralidae) on various food-plants. Zastita Bilja 35, 261-270.

Martel, C., Réjasse, A., Rousset, F., Bethenod, M.-T. \& Bourguet, D. (2003) Host-plant-associated genetic differentiation in northern French populations of the European corn borer. Heredity 90, 141-149.

Mitter, C., Farrell, B. \& Wirgman, B. (1988) The phylogenetic study of adaptive zones: has phytophagy promoted insect diversification? American Naturalist 132, 107-128.

Nagy, B. (1976) Host selection of the European corn borer (Ostrinia nubilalis Hübner) populations in Hungary. Symposium Biologica Hungarica 16, 191-195.

Painter, R. \& Weibel, D. (1951) European corn borer damage to grain sorghums. Journal of Economic Entomology 44, 796-798.

Pappers, S.M., Velde, G.V.D. \& Ouborg, N.J. (2002) Host preference and larval performance suggest host race formation in Galerucella nymphaeae. Oecologia 130, 433-440.

Patch, L. (1942) Height of corn as a factor in egg laying by the European corn borer moth in the one-generation area. Journal of Agricultural Research 64, 503-515.

Pélozuelo, L., Malosse, C., Genestier, G., Guenego, H. \& Frérot, B. (2004) Host-plant specialization in pheromone strains of the European corn borer Ostrinia nubilalis in France. Journal Chemical Ecology 30, 335-352.

Ponsard, S., Bethenod, M.-T., Bontemps, A., Pélozuelo, L., Souqual, M.-C. \& Bourguet, D. (2004) Carbon stable isotopes: a tool for studying the mating, oviposition, and spatial distribution of races of European corn borer, Ostrinia nubilalis, among host plants in the field. Canadian Journal of Zoology 82, 1177-1185.

Prokopy, R.J., Diehl, S.R. \& Cooley, S.S. (1988) Behavioral evidence for host races in Rhagoletis pomonella flies. Oecologia 76, 138-147.

Qureshi, J.A., Buschman, L.L., Throne, J.E. \& Ramaswamy, S.B. (2005) Adult dispersal of Ostrinia nubilalis Hübner (Lepidoptera: Crambidae) and its implications for resistance management in Bt-maize. Journal of Applied Entomology 129, 281-292.

Rundle, H. \& Nosil, P. (2005) Ecological speciation. Ecology Letters 8, 336-352.

SAS (1989) JMP user's guide. SAS Institute, Cary, NC, USA. 
Savinelli, C., Bacheler, J. \& Bradley, J.R. (1988) Ovipositional preferences of the European corn borer (Lepidoptera: Pyralidae) for field corn and cotton under field cage conditions in North Carolina. Environmental Entomology 17, 688-690.

Schluter, D. (2001) Ecology and the origin of species. Trends in Ecology \& Evolution 16, 372-380.

Schurr, K. \& Holdaway, F. (1970) Olfactory responses of female Ostrinia nubilalis (Lepidoptera: Pyraustinae). Entomologia Experimentalis et Applicata 13, 455-461.

Sezer, M. \& Butlin, R.K. (1998) The genetic basis of oviposition preference differences between sympatric host races of the brown planthopper (Nilaparvata lugens). Proceedings of the Royal Society of London Series B 265, 2399-2405.

Showers, W., Reed, G., Robinson, J. \& Derozari, M. (1976) Flight and sexual activity of the European corn borer. Environmental Entomology 5, 1099-1104.

Showers, W., Hellmich, R.L., Derrick-Robinson, M.E. \& Hendrix, W. (2001) Aggregation and dispersion behaviour of marked and released European corn borer (Lepidoptera: Crambidae) adults. Environmental Entomology 30, 700-710.
Spangler, S. \& Calvin, D. (2000) Influence of sweet corn growth stages on European corn borer (Lepidoptera: Crambidae) oviposition. Environmental Entomology 29, 1226-1235.

Thomas, Y., Bethenod, M.-T., Pélozuelo, L., Frérot, B. \& Bourguet, D. (2003) Genetics isolation between two sympatric host-plant races of the European corn borer, Ostrinia nubilalis Hübner. I. Sex pheromone, moth emergence timing, and parasitism. Evolution 57, 261-273.

Via, S. (2001) Sympatric speciation in animals: the ugly duckling grows up. Trends in Ecology \& Evolution 16, 381-390.

Via, S. \& Hawthorne, D.J. (2002) The genetic architecture of ecological specialization: correlated gene effects on host use and habitat choice in pea aphids. American Naturalist 159, S76-S88.

Vilkova, N. \& Frolov, A. (1978) Relations of maize and hemp populations of the European corn borer with their food plants in the North Caucasus. Bulletin Vsesoyuznogo Instituta Zashchiti Rastenii 43, 37-41.

Ward, L.K., Hackshaw, A. \& Clarke, R.T. (2003) Do food-plant preferences of modern families of phytophagous insects and mites reflect past evolution with plants? Biological Journal of the Linnean Society 78, 51-83. 